\title{
Floral transition in Origanum vulgare L.: Anatomical analysis across phenological stages in response to different photoperiodic regimes
}

\author{
Vanina Davidenco $^{1^{*}}$, Lina Seisdedos ${ }^{1}$, Selva B. Núñez ${ }^{1}$, and Juan A. Argüello ${ }^{1}$
}

\begin{abstract}
Knowledge about the specific characteristics of floral transition process in oregano (Origanum vulgare L.) is scarce. Photoperiod is one of the environmental factors regulating oregano development. The aim of this study was to evaluate anatomical changes associated with the phenological transition from vegetative to floral stages of $O$. vulgare L. subsp. vulgare (Compacto ecotype) and $O$. vulgare L. subsp. hirtum (Link) Ietsw. (Criollo ecotype), in response to day length variations. These two traditional subspecies were grown under natural and artificially 6-h extended photoperiod. Phenology and internal floral transition did not follow a single evolution pattern, since these processes respond to complex geneenvironment interactions. In the oregano subspecies studied, transition from vegetative to reproductive stages presented an intermediate step, consisting of the formation of an inflorescence meristem. Thus, floral transition occurred gradually and acropetally along the floral axis. Within the floral meristem, the appearance of reproductive perianthic pieces also occurred acropetally. Extended photoperiod seemed to act as a signal accelerating the floral transition process of the meristems, which confirms that oregano is a long-day plant. In addition, phenological and anatomical analyses confirmed that Criollo ecotype was most sensitive to photoperiodic lengthening, as evidenced by an earlier bud development all along the floral branch.
\end{abstract}

Key words: Bud anatomy, flowering pattern, Origanum vulgare subsp. hirtum, Origanum vulgare subsp. vulgare, phenology, photoperiodic sensitivity.

\section{INTRODUCTION}

Oregano (Origanum spp.) is one of the most important aromatic plants worldwide (Kintzios, 2002; De Mastro et al., 2004; Al-Kiyyam et al., 2008). In Argentina, oregano production has been steadily increasing in the last years (Argüello et al., 2012), as shown by the remarkable export growth (MAGyP, 2010). Oregano leaves and inflorescences are used as a spice for foods and beverages, and its essential oil is of interest for food preservation and stability (Economakis et al., 1999; Farías et al., 2010). Maximum essential oil content is reached at flowering (Berghold et al., 2008; Kizil et al., 2008; Sellami et al., 2009), a phenological phase of high agronomic importance in this genus. However, knowledge about the specific characteristics of the floral transition process in oregano is scarce.

From an anatomical perspective, qualitative changes generated at the meristematic level in plants indicate the beginning of the reproductive phase. Unfortunately, in

\footnotetext{
${ }^{1}$ Universidad Nacional de Córdoba, Facultad de Ciencias Agropecuarias, Valparaíso s/n, Ciudad Universitaria (5000), Córdoba, Argentina.

"Corresponding author (vdavidenco@agro.unc.edu.ar).

Received: 18 September 2013.

Accepted: 14 February 2014

doi:10.4067/S0718-58392014000300014
}

most crops the external events (e.g. flowering) are usually retarded with respect to meristematic changes, such as floral transition (Coupland, 1995); therefore, floral transition is not often easily observed phenologically, because of the difference in timing between differentiation of a floral organ and its external manifestation (Tooke and Battey, 2010). In addition, such timing responds to both genetic and environmental factors, as well as their interaction (Mouradov et al., 2002). Considering that phenology is related to timing of events during a crop cycle, it would be important to establish a parallelism between phenological characters and meristematic activity in oregano.

When plants are induced to flowering, vegetative meristems become floral meristems and have determinate growth; hence, their activity stops once formation of all floral pieces is complete. However, in species whose reproductive structures are organized into inflorescences, such as oregano, reproductive meristems have indeterminate growth, and their activity is maintained by repeating a single pattern, forming floral meristems in the periphery (Taiz and Zeiger, 2006).

The manner in which this transition process occurs defines the disposition of flowers on the branches or the stem tip, and the final morphology of the flower branch. Accordingly, the genus Origanum has dense flowers in verticillasters arranged in dense spikes, grouped in globose and/or elongated epicastros, which form terminal 
and corymbose inflorescences (Rouquaud and Videla, 2000; Mosquero et al., 2005).

In several species, characterizing the flower differentiation process and its duration is of interest to identify the factors involved in the initiation of such process (Osuna Enciso et al., 2000). In Prunus, Buban and Faust (1982) found that the first sign of floral differentiation is flattening of the meristematic apex, followed by the appearance of the sepal primordia. Later stages of morphogenesis consist of the differentiation of the remaining floral cycles, and in many species it may occur in an acropetal direction (Meza and Bautista, 2005; Jedrzejuk and Szlachetka, 2005; Evans and Dickinson, 2005).

Oregano is a long-day plant (Circella et al., 1995); hence, light is one of the most important factors regulating floral transition. Although the initiation of floral transition requires the increase of day length, local populations show certain variability in the initiation of flowering (Argüello et al., 2012). Accordingly, preliminary assays of photoperiod response involving two subspecies of Origanum vulgare L. confirmed that under artificial lengthening of light hours, subsp. hirtum (Criollo ecotype) showed greater sensitivity than subsp. vulgare (Compacto ecotype), and therefore earlier flowering (Davidenco et al., 2012).

The aim of this work was to study the anatomy of floral transition in O. vulgare subsp. vulgare (Compacto ecotype) and $O$. vulgare subsp. hirtum (Link) Ietsw. (Criollo ecotype), in response to phenological changes associated with variations in photoperiod.

\section{MATERIALS AND METHODS}

\section{Biological material and characterization of the experimental site}

Plants of two oregano subspecies were used, Compacto ecotype and Criollo ecotype, which correspond taxonomically to Origanum vulgare subsp. vulgare and Origanum vulgare subsp. hirtum (Link) Ietsw., respectively (Torres et al., 2012). The type specimens of both subspecies were deposited at the ACOR herbarium (Universidad de Cordoba [UNC], Facultad de Ciencias Agropecuarias [FCA]; named AMP 3482 and AMP 3483 , respectively). Those plants were selected from a collection of 1-yr-old mother plants. They were transplanted into $10 \mathrm{dm}^{3}$ pots containing a substrate of soil and vermiculite $(1: 1)$ on 1 September 2010. The plants were irrigated every $3 \mathrm{~d}$ to complement natural rainfall and therefore to avoid water stress throughout the assay. To obtain a uniform plant size, $5 \mathrm{~cm}$-stem height plants were cut $5 \mathrm{~d}$ after transplanting. The photoperiodic assay was conducted at the Experimental Field of UNC, FCA, located in Capilla de los Remedios, Córdoba (31 $26^{\prime}$ 'S; $63^{\circ} 49^{\prime}$ W, 360 m a.s.1.), Argentina, from 14 September to 14 December 2010; mean annual temperature is $17.7^{\circ} \mathrm{C}$ and annual rainfall is $794 \mathrm{~mm}$.

\section{Treatments and experimental design}

A two-factor experimental design with two levels of subspecies and photoperiod was used, resulting in four treatments. The subspecies were Compacto and Criollo ecotypes; photoperiod levels were Natural (NP) and 6-h extended photoperiod (EP), which were imposed from 14 September, with an actual photoperiod of $11 \mathrm{~h} 47 \mathrm{~min}$, to 14 December 2010, with actual photoperiod of $14 \mathrm{~h} 1$ min. Extension of day-light hours was achieved by two low-intensity fluorescent tube lights which provided a radiation of $3.08 \mu \mathrm{mol} \mathrm{m} \mathrm{m}^{-2} \mathrm{~s}^{-1}$ fixed to a portable acrylic frame placed $90 \mathrm{~cm}$ above the ground. The lights were connected to a timer that automatically turned the light on and off. To maintain a 6-h difference between NP and EP, the timer was set weekly. Pots of EP treatment were placed under the artificial light structure, and radiation provided only increased by $2 \%$ the midday solar radiation under a sunny sky. The purpose of this treatment was to exaggerate the long-day condition.

The experimental design consisted of a split-plot design, with photoperiodic level as the main plot and subspecies as the subplot. Each experimental unit, i.e. pot, was repeated three times.

Phenological, anatomical, and physiological variables Developmental stages were identified on the basis of external morphological characteristics, and the plant cycle was divided into vegetative, reproductive, and transitional stages. Thus, three phenological stages were defined: i) Vegetative (V), when stems showed undeveloped axillary buds; ii) initiation of floral branch (IFB), when $50 \%$ stems of each pot presented fully developed axillary buds, and a group of leaves at the apex phenotypically associated with the further development of a floral branch; and iii) floral initiation (FI), when at least one flower was open in $10 \%$ stems of each pot.

Terminal segments of the main axes were collected at three times: $24 \mathrm{~d}$ after initiation of the experiment (DAI) (T1); 36 DAI (T2), and 52 DAI (T3). These times were selected based on the phenological progress of the most precocious treatment (Criollo ecotypeEP). Axillary buds of the inflorescence meristem were evaluated, fixed in FAA (formalin:glacial acetic acid: $70 \%$ ethanol at 5:5:90 by volume). Buds were sectioned at $12 \mu \mathrm{m}$, and permanent slides of longitudinal serial sections of apical and axillary buds were prepared using conventional techniques (D'Ambrogio de Argüeso, 1986). Sections were stained with Safranin-Astra Blue (Luque et al., 1996). Observations were made with optical microscope (Zeiss Standard K, Oberkochen, Germany), and microphotographs were taken with a digital camera (Nikon Coolpix S10, Nikon, Tokyo, Japan).

The physiological variables were i) duration of phenological stages vegetative (V), initiation of floral branch (IFB), and floral initiation (FI); measured as the time elapsed between initiation of one stage and 
the next one (for $\mathrm{F}$, it was full blooming) in days and degree days $\left({ }^{\circ} \mathrm{Cd}\right)$ accumulated from the beginning of the photoperiodic assay; ii) thermal time (TT) accumulated until floral transition. Accumulated TT was calculated from the beginning of the assay (14 September) by adding up the mean daily temperature and then subtracting the base temperature of the crop $\left(0{ }^{\circ} \mathrm{C}\right)$. Mean temperature at the experimental site was obtained from a standard weather station installed 200 $\mathrm{m}$ away from the assay site.

\section{Statistical analysis}

Thermal time data were subjected to an ANOVA and comparison of means was performed with Fisher's LSD test with a significant level at $5 \%$.

\section{RESULTS}

Phenological phases identified for each subspecies used for the anatomical evaluation of buds and, consequently, for establishing a comparison between the evolution of internal (meristematic) and external development, are shown in Figure 1. Transition from vegetative to reproductive stages was observed within inflorescence meristems. This structure produced bracts, as well as floral meristems in its axils, which was repeated all along the floral branch (Figure 2). The floral transition process occurred in an acropetal direction along the inflorescence axis (Figure 2). Hence, buds at an advanced stage of development were basally located and the apical bud of the inflorescence meristem remained at vegetative stage.

The anatomical analysis of buds collected at 24 DAI showed that in all treatments buds were at vegetative stage, with a dome-shaped apical vegetative meristem with leaf primordia (Figure 3), although in the phenological analysis indicated that Criollo ecotype under EP already had characteristics of IFB (Figure 1.B2 and Figure 4). At 36 DAI, buds under NP remained at vegetative stage (Figure 5). Under EP, beginning of floral transition was observed in both subspecies; in Criollo ecotype this evidence was pronounced, since the stamens were formed. In Compacto ecotype, the apex was flattened and the sepal swellings were formed (Figure 5). Criollo ecotype completed floral transition before Compacto ecotype and consequently, the thermal time requirement of Criollo ecotype was below $554{ }^{\circ} \mathrm{Cd}$ (Figure 4). At 52 DAI, in both subspecies under NP, vegetative meristems changed into reproductive meristems, without reaching full maturity, i.e. Compacto ecotype had a flattened apex and Criollo ecotype already showed signs of floral cycles
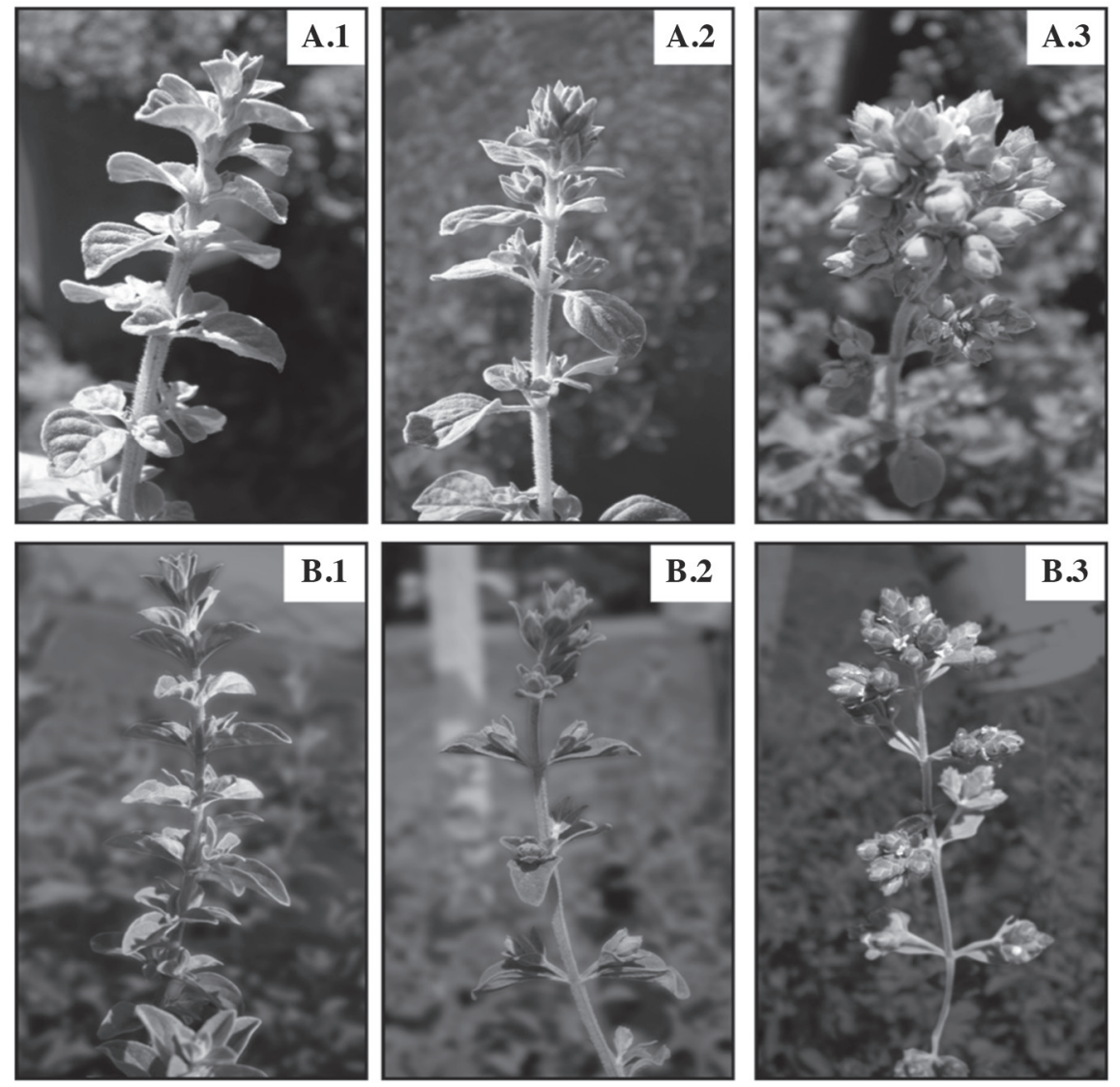

Figure 1. Phenological stages identified in Compacto ecotype (A) and Criollo ecotype (B); (1) vegetative; (2) initiation of floral branch; (3) flowering initiation. 


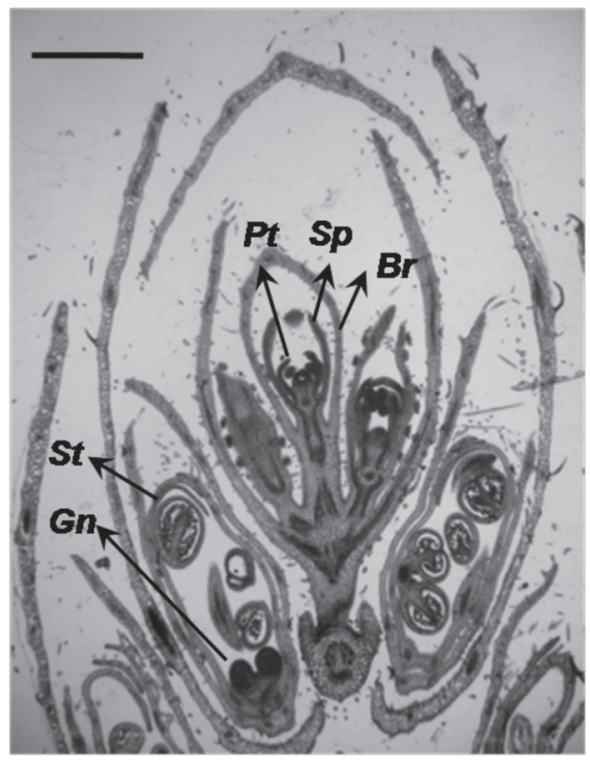

Figure 2. Inflorescence meristem anatomy of Origanum vulgare subspecies. Bract with floral meristem in its axil (Br), floral cycles, sepals (Sp); petals (Pt), gynoecium (Gn), stamens (St). Bar $=700 \mu \mathrm{m}$.

(Figure 6). Therefore, thermal time requirement to floral transition for NP was about $864{ }^{\circ} \mathrm{Cd}$ for both subspecies (Figure 4). In EP treatment apices of both subspecies showed full and mature floral cycles, with Criollo ecotype consistently showing a trend for more advanced maturity than Compacto ecotype (Figure 6), as already noted at 36 DAI (Figure 5).

\section{DISCUSSION}

The comparative analysis between crop phenological phases and the development of floral transition process showed differences in timing between the external manifestation (phenophase IFB), and the meristem change from vegetative to reproductive stage. Thus, in some cases floral transition is retarded regarding IFB stage, i.e.
Criollo ecotype under EP at 24 DAI (Figure 3 and 4); in other cases, start of IFB is quite retarded with respect to the floral transition process, i.e. Compacto ecotype under NP, at $52 \mathrm{DAI}$ (Figures 4 and 6). This phase lag was related to the photoperiodic regime and to the differential response of each subspecies, and is in agreement with the reported complexity of genetic-environmental interactions that hinder the definition of flowering process (Mouradov et al., 2002; González et al., 2002).

The earliest stages of floral bud differentiation were identified by the lengthening of the primary axis of buds, as reported for other species (Osuna Enciso et al., 2000). In oregano, lengthening of the main axis of the inflorescence is accompanied by the beginning of floral branches at the lower nodes, to form secondary axes. This situation describes an indeterminate system (Perreta and Vegetti, 2005), i.e. an open axis system (Rua, 1999) in which the apical bud of the floral branch remains at vegetative stage.

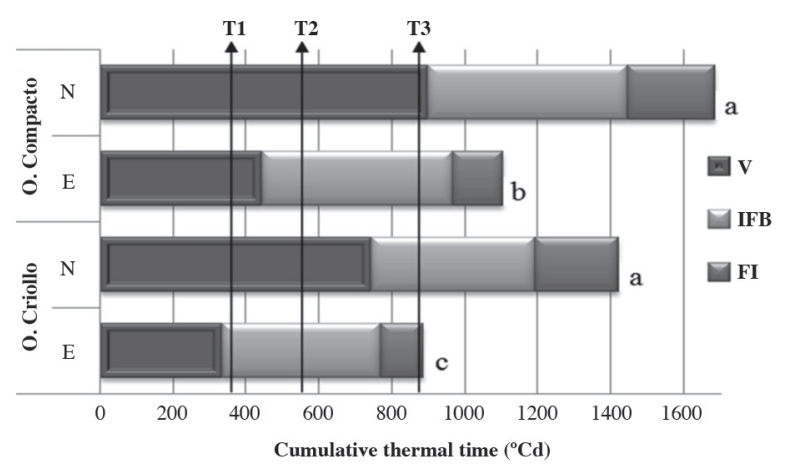

Arrows indicate the anatomical evaluation times: $24 \mathrm{~d}$ after initiation of experiment (DAI) (T1); 36 DAI (T2); 52 DAI (T3).

Different letters indicate significantly different means of cycle length according to Fisher LSD test $(\mathrm{P} \leq 0.05)$.

$\mathrm{V}$ : Vegetative; IFB: initiation of floral branch; FI: floral initiation.

Figure 4. Cumulative thermal time $\left({ }^{\circ} \mathrm{Cd}\right)$ required at different phenological phases (V, IFB, FI) in the Origanum subspecies Compacto and Criollo ecotypes under natural (N) and extended (E) photoperiod regimens.

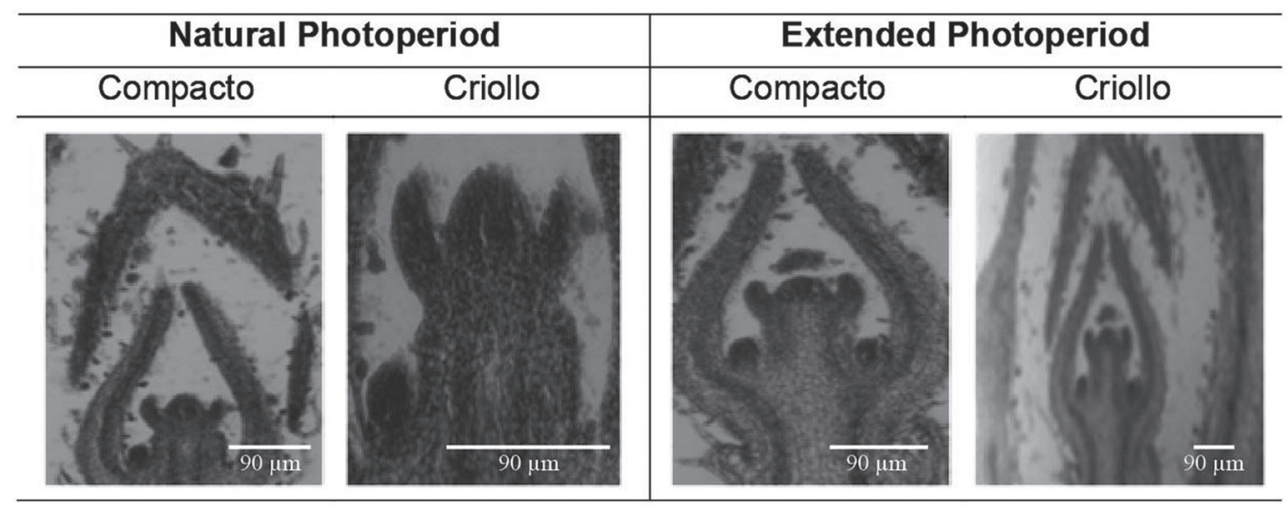

DAI: Days after initiation of the experiment.

Figure 3. Axillary bud anatomy at $24 \mathrm{~d}$ after initiation of experiment, at a cumulative thermal time of $360{ }^{\circ} \mathrm{Cd}$, in the $\mathrm{Origanum}$ subspecies Compacto and Criollo ecotypes, under two photoperiod regimes. 


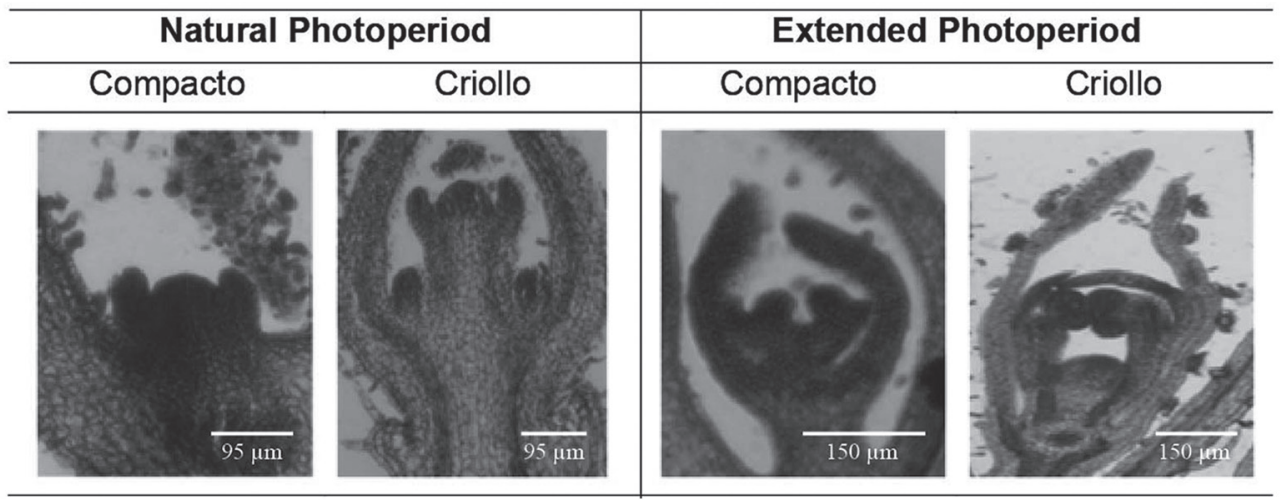

DAI: Days after initiation of the experiment.

Figure 5. Axillary bud anatomy at $36 \mathrm{DAI}$, at a cumulative thermal time of $554^{\circ} \mathrm{Cd}$ in the Origanum subspecies Compacto and Criollo ecotypes, under natural and extended photoperiod regimes.

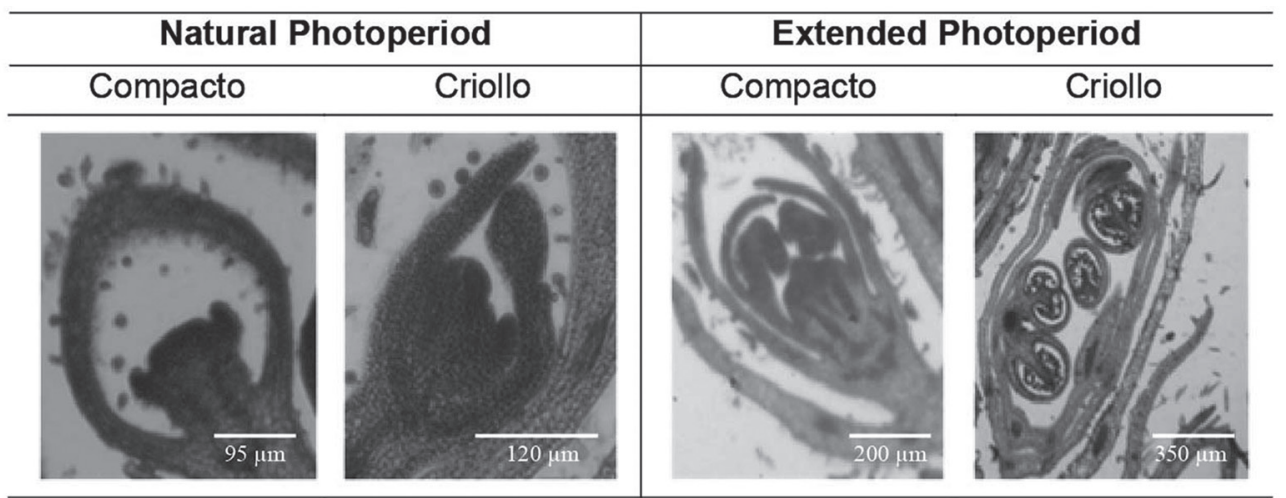

DAI: Days after initiation of the experiment.

Figure 6. Floral axillary bud anatomy at $52 \mathrm{DAI}$, at a cumulative thermal time of $864^{\circ} \mathrm{Cd}$ in the Origanum subspecies Compacto and Criollo ecotypes, under natural and extended photoperiod regimes.

In oregano there is an intermediate step during the transition from vegetative to floral meristem, which consists of the formation of an inflorescence meristem. This meristem produces bracts as well as floral meristems in its axils and is multiplied all along the floral branch (Taiz and Zeiger, 2006). In the axil of each bract a floral bud was formed, ending with the formation of a flower. Moreover, the floral transition process occurred gradually along the floral axis and in an acropetal direction.

Anatomical analysis of buds showed that dome-shaped vegetative apices developed into reproductive apices, identified by the presence of stamens and carpels. The experimental evidence presented here shows that the development of the floral cycles occurs in acropetal direction. First, sepal primordia developed, followed by petals, stamens and finally swellings, separately from each of the four uniovulate carpels, forming the gynoecium. Therefore, the degree of development of the floral cycles responded differentially, depending on the photoperiod regime.

The extended photoperiod anticipated the transition of morphogenic process all along the floral branch for the two subspecies, confirming the response of oregano as a long-day plant (Dudai et al., 1989; Circella et al., 1995). Under extended photoperiod, the earlier development of reproductive buds of Criollo ecotype than of Compacto ecotype (Figure 5) are consistent with observations reported in previous works of phenological determination (Davidenco et al., 2012), in which the thermal time requirement to complete the IFB phenophase is lower for Criollo ecotype than for Compacto ecotype.

\section{CONCLUSIONS}

The floral transition process in oregano occurs gradually and in an acropetal direction, whereas the inflorescence meristem develops along the floral branch. The appearance of perianth and reproductive parts occurs in an acropetal direction and the degree of development of floral cycles responds differentially to the photoperiodic regime to which the subspecies is subjected.

The anatomical-phenological analysis shows that Criollo ecotype has greater cycle precocity than Compacto ecotype under extended photoperiod, confirming a higher photoperiodic response. 


\section{LITERATURE CITED}

Al-Kiyyam, M.A., M. Turk, M. Al-Mahmoud, and A.R. Al-Tawaha. 2008. Effect of plant density and nitrogen rate on herbage yiels of marjoram under mediterranean conditions. Journal AmericanEurasian Journal of Agricultural and Environmental Science 3:153-158.

Argüello, J.A., S.B. Núñez, V. Davidenco, D.A. Suárez, L. Seisdedos, M.C. Baigorria, et al. 2012. Sistema de producción y cadena de valor del cultivo de orégano (Origanum sp.) en la Provincia de Córdoba (Argentina). Phyton International Journal of Experimental Botany 81:23-34.

Berghold, H., S. Wagner, M. Mandl, A. Thaller, M. Müller, M. Rakowitz, et al. 2008. Yield, content and composition of the essential oil of five oregano strains (Origanum vulgare L.) depending on the developmental stage. Zeitschrift fur Arznei und Gewurzpflanzen 13:36-43.

Buban, T., and M. Faust. 1982. Flower bud induction in apples: internal control and differentiation. Horticultural Review 4:174 202.

Circella, G., C. Franz, J. Novak, and H. Resch. 1995. Influence of day length and leaf insertion on the composition of marjoram essential oil. Flavour and Fragrance Journal 10:371-374.

Coupland, G. 1995. Genetic and environmental control of flowering time in Arabidopsis. Trends in Genetics 11:393-397.

D'Ambrogio de Argüeso, A.C. 1986. Manual de técnicas en histología vegetal. Editorial Hemisferio Sur, Buenos Aires, Argentina.

Davidenco, V., C.R.C. Vega, y J.A. Argüello. 2012. Respuesta fotoperiódica en Origanum vulgare ssp. vulgare y ssp. hirtum Ietsw. Impacto sobre su desarrollo y crecimiento. Revista de la Facultad de Ciencias Agrarias Universidad Nacional de Cuyo 44:1-12.

De Mastro, G., C. Ruta, and V. Marzi. 2004. Agronomic and technological assessment of oregano (Origanum vulgare ssp.) biotypes. Acta Horticulturae 629:355-364.

Dudai, N., E. Putievsky, D. Palevitch, and H. Halevy. 1989. Environmental factors affecting flower initiation and development in Majorana syriaca L. (Origanum syriacum var. syriacum). Israel Journal of Botany 38:229-239.

Economakis, C., C. Demetzos, T. Anatasaki, V. Papazoglou, M. Gazouli, A.C. Loukis, et al. 1999. Volatile constituents of bracts and leaves of wild and cultivated Origanum dictamnus L. Planta Medica 65:189-191.

Evans, R.C., and T.A. Dickinson. 2005. Floral ontogeny and morphology in Gillenia ("Spiraeoideae") and subfamily Maloideae C. Weber (Rosaceae). International Journal of Plant Sciences 166:427-447.

Farías, G., O. Brutti, R. Grau, P. Di Leo Lira, D. Retta, C. van Baren, et al. 2010. Morphological, yielding and quality descriptors of four clones of Origanum spp. (Lamiaceae) from the Argentine Littoral region Germplasm bank. Industrial Crops and Products $32: 472-480$.

González, F.G., G.A. Slafer, and D.J. Miralles. 2002. Vernalization and photoperiod responses in wheat pre-flowering reproductive phases. Field Crops Research 74:183-195.
Jedrzejuk, A., and W. Szlachetka. 2005. Development of flower organs in common lilac [Syringa vulgaris L.] cv. Mme Florent Stepman. Acta Biologica Cracoviensia. Series Botanica 47:41-52.

Kintzios, S.E. 2002. The genera Origanum and Lippia (Medicinal and Aromatic Plants-Industrial Profiles). 296 p. Taylor and Francis, London, UK.

Kizil, S., A. Ipek, N. Arslan, and K.M. Khawar. 2008. Effect of different developing stages on some agronomical characteristics and essential oil composition of Oregano (Origanum onites). New Zealand Journal of Crop and Horticultural Science 36:71-76.

Luque, R., H.C. Sousa, e J.E. Kraus. 1996. Estudio comparativo dos métodos de coloração de Röeser (1972) modificado e Kropp (1972) visando a subtitução do Azul de Astra por Azul de Alcião 8 GS ou 8 GX. Acta Botanica Brasilica 10:199-212.

MAGyP. 2010. Hierbas aromáticas y especias. Informe Sectorial $\mathrm{N}^{\circ}$ 3. Alimentos argentinos, Anuarios. Ministerio de Agricultura, Ganadería y Pesca, Buenos Aires, Argentina.

Meza, N., y D. Bautista. 2005. Fenología de la floración en dos variedades de níspero. Agronomía Tropical 55:203-215.

Mosquero, M., M. Angeles, R. Juan, y J.E. Pastor Díaz. 2005. Morfología y anatomía de núculas de Origanum L. (Lamiaceae) del suroeste de España. Anales de Biología 27:23-28.

Mouradov, A., F. Cremer, and G. Coupland. 2002. Control of flowering time: Interacting pathways as a basis for diversity. The Plant Cell Online 14:111-130.

Osuna Enciso, T., E.M. Engleman, A.E. Becerril Román, R. Mosqueda Vázquez, M. Soto Hernández, y A. Castillo Morales. 2000. Iniciación y diferenciación floral en mango "manila". Agrociencia 34:573-581.

Perreta, M., y A. Vegetti. 2005. Patrones estructurales en las plantas vasculares: una revisión. Gayana. Botánica 62:9-19.

Rouquaud, E., y M. Videla. 2000. Oréganos de Mendoza (Argentina). Revista de la Facultad de Ciencias Agrarias. Universidad Nacional de Cuyo 32:23-32.

Rua, G.H. 1999. Inflorescencias. Bases teóricas para su análisis. Sociedad Argentina de Botánica, Buenos Aires, Argentina.

Sellami, I.H., E. Maamouri, T. Chahed, W.A. Wannes, M.E. Kchouk, and B. Marzouk. 2009. Effect of growth stage on the content and composition of the essential oil and phenolic fraction of sweet marjoram (Origanum majorana L.) Industrial Crops and Products 30:395-402

Taiz, L., and E. Zeiger. 2006. Plant physiology. Sinauer Associates, Sunderland, Massachusetts, USA.

Tooke, F., and N.H. Battey. 2010. Temperate flowering phenology. Journal of Experimental Botany 61:2853-2862.

Torres, L.E., P.C. Brunetti, C. Baglio, P.G. Bauzá, A.G. Chaves, Y. Massuh, et al. 2012. Field evaluation of twelve clones of oregano grown in the main production areas of Argentina: Identification of quantitative trait with the highest discriminant value. ISRN Agronomy 2012. Article ID 349565. 10 p. doi: $10.5402 / 2012 / 349565$. 